\title{
ECO-INNOVATIONS: DIFFERENCES IN THE TURNOVER OF ENGINEERING AND THE ELECTRICAL INDUSTRY FIRMS
}

\author{
Nina Bockova ${ }^{1}$, Tomas Meluzin ${ }^{2}$ \\ ${ }^{1,2}$ Department of Economics, Faculty of Business and Management, \\ Brno University of Technology, Kolejní 2906/4, Brno, Czech Republic \\ E-mails: ${ }^{1}$ bockova@fbm.vutbr.cz (corresponding author); ${ }^{2}$ meluzint@fbm.vutbr.cz
}

\begin{abstract}
This paper aims to examine the similarities between innovative companies in the Engineering and the Electrotechnical industry in the Czech Republic. The main question is whether R \& D spending in companies with eco-innovation leads to a rise in turnover even in a short period of time. The paper uses the Burea Van Dijk database - Amadeus as a data source. This data source includes 186 large enterprises with information on employee's numbers, turnover, sector affiliation and R \& D expenditure. A binomial test of statistical significance was used for the comparison of the two groups of companies. The authors find that approximately one-third of enterprises record revenue slump. There was no statistically significant difference at the level of significance $\alpha=0,05$ between the shares of enterprises with eco-innovations that showed a decrease in turnover.
\end{abstract}

Keywords: engineering industry, R\&D expenditure, eco-innovation, turnover, binomial distribution.

JEL Classification: C12, G39, L64, O47.

\section{Introduction}

Innovation policy is a typical issue in advanced world economies. European Union Member states commited to the Europe 2020 strategy to meet the target of achieving the $3 \%$ of GDP investment in $\mathrm{R} \& \mathrm{D}$. The Czech Republic revised this target: $3 \%$ into National target: $1.1 \%$ (public sector only). The closest to the target was in the year 2014 when with the value of $1.97 \%$ closely met the average the EU-28. In the following years there was a decline, especially due to the rapid pace of growth in GDP and in the year 2016 was Gross Domestic Expenditure on R\&D (GERD) only $1.69 \%$. To a large extent, it has caused a drop in revenues from the European Union. In 2016 EU contributed only 2.7 billion CZK to the Czech Research and Development, which is 11 billion less than in previous year. In 2015, the funds from the previous programming period have yet to be used, new projects have not yet been activated. Although total R \& D expenditures decreased in 2016, they were still about half as high as ten years ago. As the fastest growing item, wages were shown, which for the first time accounted for more than half of the total $\mathrm{R} \& \mathrm{D}$ expenditure. The largest amount of funds for Czech research is spent on the business sector for a long time. It is also the only sector in which spending has risen. As a result, the ratio of business and public resources to research and development is increasing. Most investment in research and development are in the automotive industry. The importance of the electrotechnical and engineering industries also grows. To protect the environment and make EU industry more competitive, these need technologies, processes and business models that use resources more efficiently. We call these solutions "ecoinnovation" (EI) (European Commission, 2015).

This paper examines whether there are statistically significant differences among large companies in selected manufacturing sectors. There is not yet a study examining in detail the enterprises of the manufacturing industry in the Czech Republic.

This study is divided into five parts. Section 1 reports on eco-innovations and hitherto published findings. Section 2 explains the selected statistical files, the methodology and the use of statistical methods. Part 3 lists the results of the study and discusses them from an economic point of view. Section 4 identifies restrictions on studies and suggests future space for further study. Section 5 concludes the research with an evaluation. 


\section{Literature review}

The organizational eco-innovations are defined as the changes in companies' management instruments (eco-audits) and innovations in services (management of power demand and waste transportation). They require, therefore, new infrastructure and system changes that reach far beyond the adoption of a certain technology. The third group consists of the social eco-innovations, concerning new patterns of sustainable consumption that have drawn increasing attention and are considered as changes in people values and their life styles for sustainability. Lastly, the institutional eco-innovations are characterized as innovative institutional responses to the problems of sustainability promoted by local networks and agencies, global governance, and international commerce. They are viewed as a fundamental basis for the sustainability policy (Pacheco et al., 2017). In the scientific literature are often discussed barriers to the introduction of ecoinnovation. SMEs and barriers to eco-innovation in the European Union are analysed by exploring different firm profiles in the six clusters (Marin, Marzucchi, \& Zoboli, 2015). Only recently, some focus has been placed on the different types of knowledge, competencies and resources that companies acquire- develop to become eco-innovators (e.g. De Marchi \& Grandinetti, 2013; Ghisetti, Marzucchi, \& Montresor, 2015; Ketata, Sofka, \& Grimpe, 2015; Raudeliūnienè, Davidavičienè, \& Jakubavičius, 2018). Important for the implementation of eco-innovation is a risk management decision for more investments. Liao (2005) analysed the technology management methodlogies and applications as a literature review from 1995 to 2003. A flexible framework is proposed for evaluating technology management activities of different sized firms based on technology management as a dynamic capability (Cetindamar, Phaal, \& Probert, 2009). The firm performance model is structured on the relationships between firm size, prospector strategy, the architecture of information technology and firm performance (Kalkan, Erdil, \& Çetinkaya, 2011). The relations between technology sourcing and appropriability regimes are analysed by a conceptual framework based on technology sourcing, appropriability regimes, and new product development (Xu, Huang, \& Gao, 2012).

On one hand, the discussion on innovation has been strictly concerned about economic issues such as competitiveness, demand pressures and investment. On the other hand, the environmental area has hesitated to incorporate the processes of technological innovation, for example in a case study of Poland and Hungary (J. Przychodzen \& W. Przychodzen, 2015). Triguero, MorenoMondéjar, and Davia (2013) divided economic factors into two categories: Cost, expenses and return on investment and market share and new market potential. Through an EU-funded research project, EcoWater has developed a conceptual framework and methodology for assessing ecoefficiency on the meso level, and the proposed methodological framework has been applied to eight alternative water use systems, revealing their environmental weaknesses and identifying potential opportunities for eco-efficiency improvement (Levidow, Lindgaard-Jørgensen, Nilsson, Skenhall, \& Assimacopoulos, 2016).

As for the Policy variable, our qualitative review of previous papers outlines that the main difference in empirical models that estimate the effect of policy on EI is the choice made with respect to the policy instrument. This can either be monetary, such as the existence of grants, public funds or subsidies to stimulate EI (Cuerva, Triguero-Cano, \& Córcoles, 2014). There are currently a number of studies on technological innovation and processes as well as studies about environmental sustainability, but there are relatively scarce research and few actions taken to integrate these two themes, which results in theoretical and methodological uncertainties to SMEs.

An empirical study by the Spanish manufacturing industry indicates that remarkable differences are in place, depending on whether EIs target efficiency or non-efficiency related environmental improvements. Marzuchi and Montresor evidence also shows that internal and external knowledge turn out difficult to combine, both within and across modes (Marzucchi \& Montresor, 2017).

Next empirical analysis from Spain confirms the existence of distinctive features in relation to the drivers of investment in eco-innovation (Costa-Campi, García-Quevedo, \& Martínez-Ros, 2017).

Opinion polls conducted by the European Commission (2015) show a lower environmental awareness in Eastern European countries compared to the European average. In the EU, 83\% (in 2012) of the persons questioned stated that a product's impact on the environment is very or rather important for them when deciding on a purchase. These figures amounted to only $62 \%$ in 
the Czech Republic and 71\% in Bulgaria (Horbach, 2016).

\section{Data and methodology}

Own research was conducted on selected industrial enterprises. Industry, which occupies an essential position in the Czech economy as it provides about a third of its performance in the year 2016, it participated in the formation of gross value added of $32.1 \%$, manufacturing industry then $27.1 \%$. The Czech Republic belongs in the framework of the EU-28 to the States with the highest proportion of manufacturing industry to gross value added.

It is also important its share of total employment, which in the year 2016 amounted to $26.6 \%$. From the perspective of the relevance of the selected enterprise's Electronics and Electrotechnical Industry and the Machinery and equipment Industry, which make up the largest proportion of enterprises with $\mathrm{R} \& \mathrm{D}$ expenditure in the manufacturing industry. Development expenditure in the years 2014-2016, see Table 1.

Table 1. Shares of total R \& D expenditure section of the processing industry (source: authors own calculation, CZSO, 2014-2016)

\begin{tabular}{|l|c|c|c|c|}
\hline \multicolumn{1}{|c|}{ Year } & 2014 & 2015 & 2016 & $\begin{array}{c}\text { Innovative } \\
\text { large } \\
\text { companies }\end{array}$ \\
\hline & \multicolumn{3}{|c|}{ Share on R\&D Exp (\%) } \\
\hline $\begin{array}{l}\text { Electronics } \\
\text { and the Elec- } \\
\text { trotechnical } \\
\text { Industry }\end{array}$ & 12.5 & 12.3 & 20.06 & 486 \\
\hline $\begin{array}{l}\text { Machinery } \\
\text { and equip- } \\
\text { ment industry }\end{array}$ & 11.9 & 11.6 & 22.63 & 660 \\
\hline
\end{tabular}

Innovative manufacturing companies (44.4\% of innovative enterprises) have identified the need to comply with existing environmental laws as the main reason for introducing eco-innovation. The survey was conducted in 2006-2008. One quarter of enterprises (25.6\%) stated the "Voluntary Code of Good Environmental Practice in the Industry" as the main reason for introducing eco-innovation. Market demand by the customer after the environmental innovation reported $15.7 \%$ of companies. Access to public procurement contracts, grant or other financial incentives, relating to ecoinnovation was $8.1 \%$ of enterprises the incentive for. The application of eco-innovation in the future, reported a $30.9 \%$ (CZSO, 2010). We were watching the impact of the introduction of ecoinnovations on the performance of innovative enterprises.

The output from the RTD 5-01 questionnaire (a): Annual Research and Development Report for 2016 was used as the secondary data source. Statistics file contains only the large innovative enterprises from NACE $26+27$ and 28. In Electronics and the Electrotechnical Industry was in the year 2014, a total of 88 innovative large companies in the Machinery and equipment Industry 98 large innovative businesses. The structure of the statistical set is listed in Table 2. The statistical set includes large innovative enterprises from the selected manufacturing industry. From it are selected businesses that focus on EI. Drop in Turnover refers to businesses that have experienced a decline in turnover between 2014 and 2016.

Table 2. Shares of total R \& D expenditure selected sections of the manufacturing industry (source: authors own calculation, CZSO, 2014-2016)

\begin{tabular}{|l|c|c|c|}
\hline & Large & $\begin{array}{c}\text { Eco } \\
\text { Innovation }\end{array}$ & $\begin{array}{c}\text { Drop in } \\
\text { Turnover }\end{array}$ \\
\hline $\begin{array}{l}\text { Electronics and the } \\
\text { Electrotechnical } \\
\text { Industry }\end{array}$ & 88 & 37 & 11 \\
\hline $\begin{array}{l}\text { Machinery and } \\
\text { equipment industry }\end{array}$ & 98 & 36 & 8 \\
\hline
\end{tabular}

Descriptive statistics for both groups of enterprises are listed in Table 3.

For the statistical comparison of the selected division was elected to test conformity of relative frequency in the two selected sectors of the processing industry. The hypothesis $\mathrm{H}_{0}$ refers to the likelihood of reduced turnover in the introduction of eco-innovation in two selected sectors of the manufacturing industry.

$H_{0}: 1 \pi=\pi_{2}$ is testing against $H_{1}: \pi_{1} \pi_{2} \neq$ at significance level $\alpha$. Point estimators of two unknown probability of success enterprises with low turnover in the samples are given by relative frequencies is an estimate of the associated relative representation of the character in both statistical files together.

$$
p_{1}=\frac{m_{1}}{n_{1}} ; p_{2}=\frac{m_{2}}{n_{2}} \text {. }
$$

If $H_{0}$ is the statistic standard normal distribution. 


$$
\begin{gathered}
U=\frac{\left(p_{1}-p_{2}\right)-\left(\pi_{2}-\pi_{1}\right)}{\sqrt{p \times(1-p)}} \times \sqrt{\frac{n_{1} \times n_{2}}{n_{1}+n_{2}}} ; \\
p=\frac{m_{1}+m_{2}}{n_{1}+n_{2}} .
\end{gathered}
$$

Critical test scope $H_{0}$ against double-sided alternative at significance level $\alpha$ is determined by quantiles of the standard normal distribution.

$$
W_{\alpha}=\left\{u: u<u_{\alpha / 2} \text { nebo } u>u_{1-\alpha / 2}\right\}
$$

\section{The decision rule I}

$H_{0}$ is rejected for $u<u_{\alpha / 2}$ or for $u>u_{1-\alpha / 2}$.

\begin{tabular}{|c|c|c|c|c|c|}
\hline \multicolumn{6}{|c|}{ Electronics and the Electrotechnical Industry } \\
\hline & & Large & Eco-innovation & Innovation Only & Drop in Turnover \\
\hline & Number & 98 & 36 & 62 & 8 \\
\hline \multirow{4}{*}{ TU14 } & Mean & $1,671,167$ & $2,206,153$ & $1,355,438$ & $2,313,954$ \\
\hline & Median & $1,160,095$ & $1,384,521$ & $1,095,716$ & $2,123,577$ \\
\hline & Modus & multiple & multiple & multiple & multiple \\
\hline & stand. dev. & $1,605,286$ & $2,014,349$ & $1,217,826$ & $1,033,739$ \\
\hline \multirow{4}{*}{ TU16 } & Mean & $1,791,656$ & $2,521,852$ & $1,367,671$ & $1,871,778$ \\
\hline & Median & $1,230,098$ & $1,659,821$ & $1,034,481$ & $1,783,295$ \\
\hline & Modus & multiple & multiple & multiple & multiple \\
\hline & stand. dev. & $1,974,998$ & $2,568,596$ & $1,385,528$ & $1,035,068$ \\
\hline \multirow{4}{*}{ EMP14 } & Mean & 543 & 590 & 515 & 593 \\
\hline & Median & 449 & 519 & 405 & 503 \\
\hline & Modus & multiple & multiple & multiple & multiple \\
\hline & \begin{tabular}{|l|} 
stand. dev. \\
\end{tabular} & 332 & 330 & 333 & 428 \\
\hline \multirow{4}{*}{ EMP16 } & Mean & 559 & 613 & 528 & 688 \\
\hline & Median & 454 & 555 & 408 & 520 \\
\hline & Modus & multiple & multiple & multiple & multiple \\
\hline & stand. dev. & 346 & 344 & 346 & 390 \\
\hline \multicolumn{6}{|c|}{ Machinery and equipment industry } \\
\hline & & Large & Eco-innovation & Innovation Only & Drop in Turnover \\
\hline & Number & 88 & 37 & 51 & 11 \\
\hline \multirow{4}{*}{ TU14 } & Mean & $4,388,798$ & $4,427,263$ & $4,360,892$ & $1,965,083$ \\
\hline & Median & $1,093,807$ & $1,595,486$ & 879,010 & $1,018,734$ \\
\hline & \begin{tabular}{|l|} 
Modus \\
\end{tabular} & multiple & multiple & multiple & multiple \\
\hline & \begin{tabular}{|l|} 
stand. dev. \\
\end{tabular} & $12,688,160$ & $8,871,927$ & $14,948,167$ & $2,352,406$ \\
\hline \multirow{4}{*}{ TU16 } & Mean & $4,997,500$ & $5,029,918$ & $4,973,981$ & $2,310,117$ \\
\hline & Median & $1,477,454$ & $1,942,787$ & $1,079,511$ & $1,397,103$ \\
\hline & \begin{tabular}{|l|} 
Modus \\
\end{tabular} & multiple & multiple & multiple & multiple \\
\hline & \begin{tabular}{|l} 
stand. dev. \\
\end{tabular} & $14,145,012$ & $9,547,991$ & $16,807,797$ & $3,128,564$ \\
\hline \multirow{4}{*}{ EMP14 } & Mean & 787 & 1,068 & 583 & 516 \\
\hline & Median & 427 & 478 & 407 & 442 \\
\hline & Modus & multiple & 327 & multiple & multiple \\
\hline & stand. dev. & 1,163 & 1,672 & 487 & 359 \\
\hline \multirow{4}{*}{ EMP16 } & Mean & 833 & 1110 & 632 & 593 \\
\hline & Median & 479 & 580 & 467 & 543 \\
\hline & \begin{tabular}{|l|} 
Modus \\
\end{tabular} & multiple & multiple & multiple & 330 \\
\hline & stand. dev. & 1,138 & 1,625 & 504 & 427 \\
\hline
\end{tabular}

$H_{0}$ is denied for $u_{\propto / 2} \leq u \leq u_{1-\propto / 2}$.

Table 3. Descriptive statistics 
The exact significance level of the test when bilateral alternative:

$$
\begin{aligned}
& p=2[1-\Phi(|u|)]=2\left[1-\int_{-\infty}^{|u|} f_{N-\text { dist }}(x) d x\right]= \\
& 2 \int_{|u|}^{+\infty} f_{N-\text { dist }}(x) d x .
\end{aligned}
$$

Function $\Phi(x)$ and $f_{-}(\mathrm{N}$-dist $)(x)$ denote distribution function and density of the standard normal distribution $N(0 ; 1)$.

The decision rule II

$H_{0}$ is rejected for $p<\propto$.

$H_{0}$ is denied for $p \geq \propto$.

For two-sided alternative hypothesis may be the numerator of test criterion in absolute value statistic, rejecting area is then determined by the $u_{1-\alpha / 2}$ (Skalská, 2013).

\section{Results}

Of each sector was selected a group of companies, both groups are independent of each other. For each statistical sample, we examine the statistical variable with the alternative distribution. The relative frequency of occurrence of the character, in our case, the annual reduction of the turnover in the selected sample, estimated the unknown likelihood of deterioration of drop in turnover in the industry, from which undertakings have been selected with eco-innovation.

Definition of hypothesis $H_{0}$ : A reduction in the annual turnover after the introduction of ecoinnovation has experienced different shares of innovative enterprises in the electrical and mechanical engineering industry.

98 large enterprises were registered in the NACE 28 survey period. Eco-innovation was reported by 36 enterprises. 8 enterprises had a deteriorated year-on-year turnover in 2014-2016, than equitation (1)

$$
p_{1}=8 / 36=0.222 \text {. }
$$

In a division of NACE 26 and 27 were modernized 88 large enterprises in the years 2014 . 37 enterprises reported the eco extreme engineering. Drop in annual turnover in the years 2014-2016 had 11 companies. A select proportion of enterprises with low turnover in the set of innovative enterprises in NACE Division 26 and 27 are (equation (1))

$$
p_{2}=11 / 37=0.297 \text {. }
$$

Descriptive statistics for the test file are shown in Table 3. if,

Estimate of the aggregate $p=19 / 73=0.260$

$$
H_{0}: \pi_{1}=\pi_{2} \text { against } H_{1}: \pi_{1} \neq \pi_{2}
$$

at the significance level $\alpha=0.05$. The assumptions for the use of limit formulas are met, if

$$
n p \geq 5, n(1-p) \geq 5 \text {. }
$$

\section{Test Criteria Value}

$$
\begin{aligned}
& u=\frac{|0.222-0.297|-0}{\sqrt{0.260 \times(1-0.260)}} \times \sqrt{\frac{37 \times 36}{37+36}}= \\
& 0.7303
\end{aligned}
$$

is less than the critical value for

$u_{1-0,05 / 2}=u_{0.975}=\operatorname{NORM} . \operatorname{S.INV}(0.975) \approx 1.96$

in the distribution of $\mathrm{N}(0 ; 1)$. We do not reject the hypothesis $\mathrm{H}_{0}$ at significance level $\alpha=0.05$. Therefore, you can interpret that at a given level of significance has not been selected for both the Division of manufacturing industry statistically significant difference between the shares of large companies, which show the reference character the annual reduction in turnover following the introduction of eco-innovation. In a standardized normal distribution is the probability of more extreme values than $u=0.73$ is equal to the see equation (2)

$$
p \cong 0.465>0,05 \text {. }
$$

The same conclusion applies to rule II. $\mathrm{H}_{0}$ is denied at the level of significance $\propto=0,05(p=0.465)$. The results did not support the alternative hypothesis of selection varying the proportion of enterprises that have drop in turnover.

The difference (equation (1)) between two statistical sets,

$$
7.51 \%=29.73 \%-22.22 \%
$$

it is not insignificant. In further research, we may be interested in the probability of error $\beta$ that would occur by incorrectly accepting $\mathrm{H}_{0}$. When $\mathrm{H}_{0}$ cannot be rejected for given statistics. Test strength $1-\beta$ then determines the probability of correct rejection $\mathrm{H}_{0}$, which in fact does not apply. If the difference is $7.51 \%$ between the sampling rates selected $\alpha=0.05$ and the given selection ranges. 


\section{Discussion and conclusions}

Studies such as del Triguero et al. (2013), Cai and Zhou (2014), Klewitz and Hansen (2014), Del Rio, Penasco, and Romero-Jordan (2016) and argue that there is a need for new surveys aimed at drivers of eco-innovation to provide a structured view of enterprises by size and type of industry. Our research contributes to discussing eco-innovation in a particular context of large manufacturing enterprises. Our sample was made up of large enterprises in the electronics, electrical and engineering industries. Our empirical data is based on a CSSO questionnaire survey from 2014 to 2016. We chose two groups of companies by random selection, just like Antonietti and Marzucchi (2014). R \& D Investments are generally perceived as a condition for the growth of the company's economic performance. Selected divisions of the manufacturing industry are the two fastest growing ones in terms of innovation. We deliberately investigated only companies that have also invested in eco-innovation, whose contribution to the economic performance of the business is being discussed (Demirel \& Kesidou, 2011; Lee \& Min, 2015). A group of companies that focused on eco-innovation was roughly the same in both divisions. $\mathrm{R} \& \mathrm{D}$ investment in the eco-innovation development was performed in 2014-2016 by 37 enterprises in the Electronics and Electrotechnical Industry, respectively 36 enterprises in and the Machinery and equipment Industry. Our research was not focused on direct return on investment. The return on investment cannot be assessed in such a short period. We assessed the existence of a statistically significant difference between enterprises that experienced a decrease in turnover over the reporting period. Using the Share Compliance Test, we determined the existence of differences between the selection of businesses. The pronounced hypothesis cannot be denied on the level of significance $\alpha$. The selection results do not support an alternative hypothesis about the different share of enterprises experiencing a deteriorated economic situation as measured by a decline in turnover in both manufacturing divisions. Finally, it is possible to conclude that, in general, the leaders of the manufacturing industry make a significant contribution to the creation of a domestic product. Short-term falls in the revenue of innovating companies are not affected.

\section{Acknowledgements}

This research was supported by the Internal Grant of Faculty of Business and management, BUT Brno No. FP 18 - Microeconomics - Interaction in the market of factors of production determined by the market of land, labour and capital.

\section{Disclosure statement}

No conflicts of financial, professional, or personal interests was reported by the authors.

\section{References}

Antonietti, R., \& Marzucchi, A. (2014). Green tangible investment strategies and export performance: a firmlevel investigation. Ecological Economics, 108, 150161. https://doi.org/10.1016/j.ecolecon.2014.10.017

Cai, W. G., \& Zhou, X. L. (2014). On the drivers of ecoinnovation: empirical evidence from China. Journal of Cleaner Production, 79, 239-248. https://doi.org/10.1016/j.jclepro.2014.05.035

Cetindamar, D., Phaal, R., \& Probert, D. (2009). Understanding technology management as a dynamic capability: a framework for technology management activities. Technovation, 29(4), 237-246. https://doi.org/10.1016/j.technovation.2008.10.004

Costa-Campi, M. T., García-Quevedo, J., \& MartínezRos, E. (2017). What are the determinants of investment in environmental R\&D?. Energy Policy, $104,455-465$. https://doi.org/10.1016/j.enpol.2017.01.024

Cuerva, M. C., Triguero-Cano, Á., \& Córcoles, D. (2014). Drivers of green and non-green innovation: empirical evidence in low-tech SMEs. Journal of Cleaner Production, 68, 104-113. https://doi.org/10.1016/j.jclepro.2013.10.049

CZSO. (2010). Reasons for introducing eco-innovation within an enterprise. Retrieved from https://www. czso.cz/documents/10180/20566153/960510a24.pdf/a 9a3c801-e396-4c70-8c16-c80b0787773d?version= 1.0 .

Del Rio, P., Penasco, C., \& Romero-Jordan, D. (2016). What drives eco-innovators? A critical review of the empirical literature based on econometric methods. Journal of Cleaner Production, 112, 2158-2170. https://doi.org/10.1016/j.jclepro.2015.09.009

De Marchi, V., \& Grandinetti, R. (2013). Knowledge strategies for environmental innovations: the case of Italian manufacturing firms. Journal of Knowledge Management, 17(4), 569-582. https://doi.org/10.1108/JKM-03-2013-0121

Demirel, P., \& Kesidou, E. (2011). Stimulating different types of eco-innovation in the UK: government policies and firm motivations. Ecological Economics, 70(8), 1546-1557.

https://doi.org/10.1016/j.ecolecon.2011.03.019

European Commission. (2015). Environment. Retrieved from http://ec.europa.eu/environment/basics/greeneconomy/innovation/index_en.htm.

Horbach, J. (2016). Empirical determinants of ecoinnovation in European countries using the community 


\section{ECO-INNOVATIONS: DIFFERENCES IN THE TURNOVER OF ENGINEERING AND THE ELECTRICAL INDUSTRY FIRMS}

innovation survey. Environmental Innovation and Societal Transitions, 19, 1-14.

https://doi.org/10.1016/j.eist.2015.09.005

Ghisetti, C., Marzucchi, A., \& Montresor, S. (2015). The open eco-innovation mode. An empirical investigation of eleven European countries. Research Policy, 44(5), 10801093. https://doi.org/10.1016/j.respol.2014.12.001

Kalkan, A., Erdil, O., \& Çetinkaya, Ö. (2011). The relationships between firm size, prospector strategy, architecture of information technology and firm performance. Procedia - Social and Behavioral Sciences, 24, 854-869. https://doi.org/10.1016/j.sbspro.2011.09.114

Ketata, I., Sofka, W., \& Grimpe, C. (2015). The role of internal capabilities and firms' environment for sustainable innovation: evidence for Germany. $R \& D$ Management, 45(1), 60-75. https://doi.org/10.1111/radm.12052

Klewitz, J., \& Hansen, E. G. (2014). Sustainability-oriented innovation of SMEs: a systematic review. Journal of Cleaner Production, 65, 57-75. https://doi.org/10.1016/j.jclepro.2013.07.017

Lee, K. H., \& Min, B. (2015). Green R\&D for eco-innovation and its impact on carbon emissions and firm performance. Journal of Cleaner Production, 108(A), 534-542. https://doi.org/10.1016/j.jclepro.2015.05.114

Levidow, L., Lindgaard-Jørgensen, P., Nilsson, Å., Skenhall, S. A., \& Assimacopoulos, D. (2016). Process ecoinnovation: assessing meso-level eco-efficiency in industrial water-service systems. Journal of Cleaner Production, 110, 54-65. https://doi.org/10.1016/j.jclepro.2014.12.086

Liao, S. (2005). Technology management methodologies and applications - a literature review from 1995 to 2003. Technovation, 25(4), 381-393.

https://doi.org/10.1016/j.technovation.2003.08.002
Marin, G., Marzucchi, A., \& Zoboli, R. (2015). SMEs and barriers to eco-innovation in the EU: exploring different firm profiles. Journal of Evolutionary Economics, 25(3), 671-705. https://doi.org/10.1007/s00191-015-0407-7

Marzucchi, A., \& Montresor, S. (2017). Forms of knowledge and eco-innovation modes: evidence from Spanish manufacturing firms. Ecological Economics, 131, 208221. https://doi.org/10.1016/j.ecolecon.2016.08.032

Pacheco, D. A., Ten Caten, C. S., Jung, C. F., Ribeiro, J. L. D., Navas, H. V. G., \& Cruz-Machado, V. A. (2017). Eco-innovation determinants in manufacturing SMEs: systematic review and research directions. Journal of Cleaner Production, 142, 2277-2287. https://doi.org/10.1016/j.jclepro.2016.11.049

Przychodzen, J., \& Przychodzen, W. (2015). Relationships between eco-innovation and financial performance evidence from publically traded companies in Poland and Hungary. Journal of Cleaner Production, 90, 253263. https://doi.org/10.1016/j.jclepro.2014.11.034

Raudeliūnienė, J., Davidavičienė, V., \& Jakubavičius, A. (2018). Knowledge management process model. Entrepreneurship and sustainability issues, 5(3), 542554. https://doi.org/10.9770/jesi.2018.5.3(10)

Skalská, H. (2013). Aplikovaná statistika. Hradec Králové: Gaudeamus.

Triguero, A., Moreno-Mondéjar, L., \& Davia, M. A. (2013). Drivers of different types of eco-innovation in European SMEs. Ecological Economics, 92, 25-33. https://doi.org/10.1016/j.ecolecon.2013.04.009

Xu, K., Huang, K. F., \& Gao, S. (2012). Technology sourcing, appropriability regimes, and new product development. Journal of Engineering and Technology Management, 29(2), 265-280. https://doi.org/10.1016/j.jengtecman.2012.03.003 